\title{
Imaging findings of glomus tumor at duodenum: a case description
}

\author{
Jongjin Yoon, Kyeongmin Kim, Sunyoung Lee \\ Severance Hospital, Yonsei University College of Medicine, Seoul, Korea \\ Correspondence to: Sunyoung Lee. Severance Hospital, Yonsei University College of Medicine, Seoul, Korea. Email: carnival0126@yuhs.ac.
}

Submitted Nov 04, 2019. Accepted for publication Mar 16, 2020.

doi: 10.21037/qims.2020.03.22

View this article at: http://dx.doi.org/10.21037/qims.2020.03.22

\section{Introduction}

Glomus tumor is a neoplasm composed of cells that resemble the perivascular modified smooth muscle cells of the glomus body (1). Although glomus tumors usually arise in the subungual region, they may occur elsewhere in the body (2). Glomus tumors in the duodenum are rare, and only four case reports have been published in the English medical literature (3-6) (Table 1). Here, we report a surgically confirmed case of glomus tumor originating from the duodenum and describe the characteristic imaging findings.

\section{Case presentation}

A 42-year-old man was admitted to our medical institution with right upper quadrant abdominal pain for 1 month. The patient had an episode of melena 3 months before the admission. He had no history of surgeries. The physical examination was unremarkable. Laboratory hematologic and coagulation tests on admission revealed no abnormalities. Tumor markers were within the normal range: carcinoembryonic antigen, $1.97 \mathrm{ng} / \mathrm{mL}$ and carbohydrate antigen 19-9, 5.7 U/mL.

On ultrasonography (US), a well-circumscribed hypoechoic mass was seen in the duodenum, measuring $2.0 \mathrm{~cm} \times 1.7 \mathrm{~cm}$ (Figure 1). Unenhanced computed tomography (CT) demonstrated hypoattenuating mass in the third portion of the duodenum, measuring $2.5 \mathrm{~cm} \times$ $1.7 \mathrm{~cm}$ (Figure 2A). The mass showed strong enhancement with a well-defined margin in the arterial phase (Figure $2 B$ ) and persistent enhancement in the portal and delayed phases (Figure 2C,D). Lesion-to-aorta enhancement ratios were $0.62,0.91$, and 0.84 in the arterial, portal, and delayed phases, respectively. Coronal arterial phase CT demonstrated central ulceration (Figure 2E). No obvious metastases or intra-abdominal lymphadenopathies were identified.

The patient underwent a laparoscopic wedge resection of the tumor. Grossly, the tumor was a wellcircumscribed intramural mass, measuring $2.5 \mathrm{~cm} \times 1.5 \mathrm{~cm}$. Microscopically, the mass involved the submucosa and muscularis propria (Figure 3A). On hematoxylin and eosin staining, the tumor was composed of uniform cells with round nuclei (Figure 3B). No nuclear atypia was seen, and the mitotic count was 0/50 high-power fields (HPF). No lymphovascular or perineural invasion was identified. Immunohistochemically, the tumor cells were positive for smooth muscle actin and collagen IV (Figure $3 C, D$ ) but negative for chromogranin A (Figure $3 E$ ). Synaptophysin was focally positive in the tumor cells (Figure $3 F$ ). Finally, the mass was diagnosed as a glomus tumor of the duodenum. The patient had an uneventful postoperative course and has remained free from the disease for a followup period of 18 months.

\section{Discussion}

Glomus tumor is a mesenchymal tumor arising from the perivascular modified smooth muscle cells of the glomus body (1). Gastrointestinal glomus tumors are rare but most frequently occur in the stomach as a subepithelial tumor (7). Epigastric discomfort is the most common symptom (8). Gastrointestinal glomus tumors often present with gastrointestinal bleeding because of ulcerations in the overlying mucosa (9). 
Table 1 Patient and tumor characteristics of the four patients with duodenal glomus tumors in the literature and the current case

\begin{tabular}{|c|c|c|c|c|c|c|c|c|c|}
\hline \multicolumn{2}{|c|}{ No.Year } & \multirow{2}{*}{$\begin{array}{l}\text { Sex } \\
M\end{array}$} & \multirow{2}{*}{$\begin{array}{l}\text { Age } \\
46\end{array}$} & \multirow{2}{*}{$\begin{array}{l}\text { Tumor } \\
\text { size } \\
2.3 \mathrm{~cm}\end{array}$} & \multirow{2}{*}{$\begin{array}{l}\text { Tumor } \\
\text { location } \\
\text { Duodenal } \\
\text { second } \\
\text { portion }\end{array}$} & \multirow{2}{*}{$\begin{array}{l}\text { Microscopic findings } \\
\text { Uniform cells with well-defined cell borders, } \\
\text { central punched-out nuclei, and faintly staining } \\
\text { or clear cytoplasm; no necrosis, mitosis, or } \\
\text { vascular invasion }\end{array}$} & \multirow{2}{*}{$\begin{array}{l}\text { Immunohistochemistry } \\
\text { SMA (+), Vimentin (+), } \\
\text { Synaptophysin (+/-), } \\
\text { Cytokeratin AE1/3 (-), } \\
\text { Chromogranin (-), } \\
\text { Serotonin (-) }\end{array}$} & \multirow{2}{*}{$\begin{array}{l}\text { Treatment } \\
\text { Surgical } \\
\text { resection }\end{array}$} & \multirow{2}{*}{$\begin{array}{l}\text { Reference } \\
\text { (3) }\end{array}$} \\
\hline 1 & 2004 & & & & & & & & \\
\hline 3 & 2011 & NR & NR & $<5 \mathrm{~cm}$ & NR & NR & NR & NR & (5) \\
\hline 4 & 2016 & $\mathrm{~F}$ & 88 & $2.1 \mathrm{~cm}$ & $\begin{array}{l}\text { Duodenal } \\
\text { bulb }\end{array}$ & NR & $\begin{array}{l}\text { SMA (+), Myosin (+), } \\
\text { Synaptophysin (+) } \\
\text { Chromogranin (-), } \\
\text { CD34 (-), CD56 (-) }\end{array}$ & NR & (6) \\
\hline 5 & 2019 & M & 42 & $2.5 \mathrm{~cm}$ & $\begin{array}{l}\text { Duodenal } \\
\text { third } \\
\text { portion }\end{array}$ & Uniform cells with round nuclei & $\begin{array}{l}\text { SMA (+), Collagen IV (+), } \\
\text { Chromogranin (-), } \\
\text { Synaptophysin (+/-) }\end{array}$ & $\begin{array}{l}\text { Surgical } \\
\text { resection }\end{array}$ & $\begin{array}{l}\text { Current } \\
\text { case }\end{array}$ \\
\hline
\end{tabular}

SMA, smooth muscle actin; (+/-), focal positive in immunohistochemistry; NR, not reported.

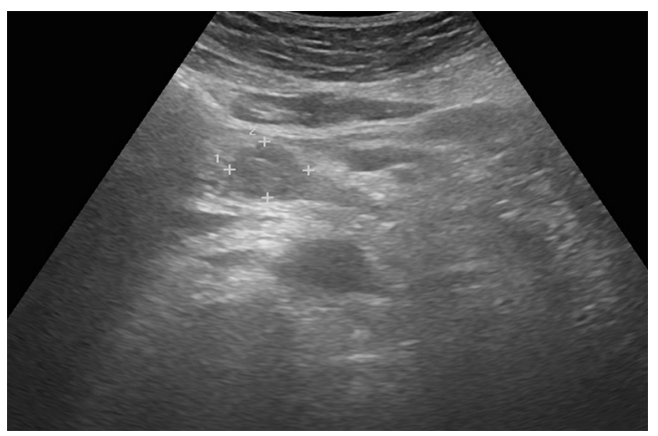

Figure 1 The duodenal glomus tumor shows a well-circumscribed hypoechoic mass on ultrasonography.

Sonographic and CT findings of gastric glomus tumors have been described in the literature. On transabdominal or endoscopic ultrasound, they appear as well-demarcated hypoechoic masses originating from the third or fourth layer of the gastric wall (10-13). On CT, gastric glomus tumors show high enhancement in the arterial phase, which reflects their hypervascular nature. In the portal and delayed phases, the tumor shows persistent enhancement (9,14-16). Gastric glomus tumors are more strongly enhanced than other wellenhancing subepithelial lesions, such as neuroendocrine tumor, some gastrointestinal stromal tumor (GIST), and heterotopic pancreas (5). In a study by Hur et al., lesion-to-aorta enhancement ratios of glomus tumors were significantly higher than those of other subepithelial lesions in the arterial, portal, and delayed phases (5). In addition, the portal phase lesion-to-aorta ratio 0.86 or greater was significant variable for differentiating glomus tumors from other subepithelial lesions (5). In our case of the duodenal glomus tumor, imaging features were similar to those previous reported for glomus tumors, showing a lesion-toaorta enhancement ratio of 0.91 in the portal phase.

Immunohistochemical findings are valuable for distinguishing glomus tumors from other subepithelial tumors (7). Gastrointestinal glomus tumors are positive for smooth muscle actin, vimentin, and collagen IV (7). Neuroendocrine tumors are positive for chromogranin A and synaptophysin (1). Glomus tumors are negative for chromogranin A, but there can be focal synaptophysin expression (1). GISTs are positive for KIT (CD117) and frequently positive for CD34 while glomus tumors are persistently negative for CD117 and occasionally positive for CD34 (7).

Although most cases of gastrointestinal glomus tumors are benign, cases of malignant behavior and metastases have been reported (7,17-19). Folpe et al. proposed the criteria for malignant glomus tumors, including tumors with a deep 

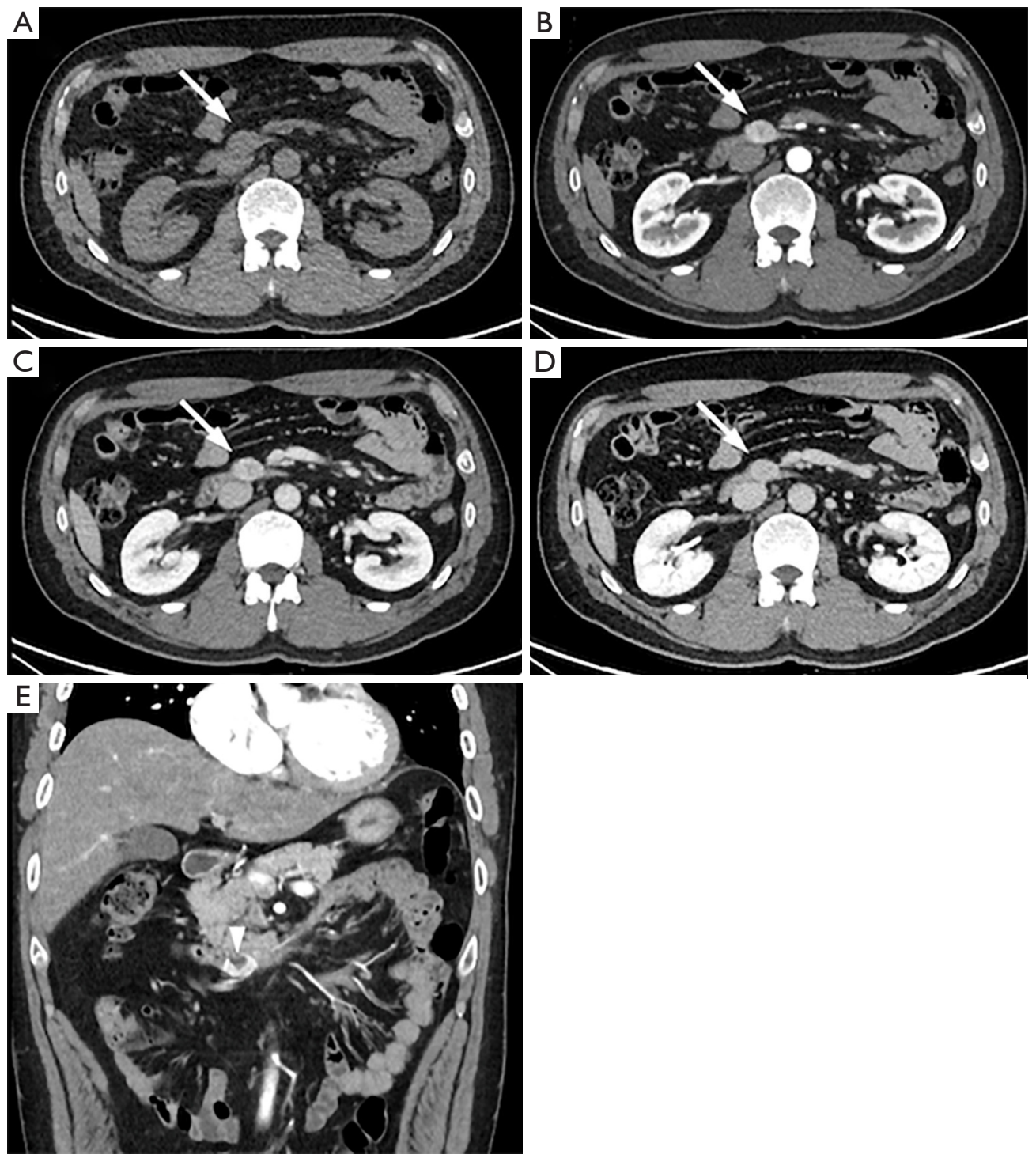

Figure 2 Computed tomography of the duodenal glomus tumor. Axial unenhanced computed tomography (CT) scan (A) shows a wellcircumscribed mass (arrow) in the third portion of the duodenum. Contrast-enhanced CT scans reveal strong enhancement in the arterial phase (B) and persistent enhancement in the portal (C) and delayed (D) phases (arrows). Coronal arterial phase CT scan (E) demonstrates central ulceration (arrow head).

location and a size greater than $2 \mathrm{~cm}$, or atypical mitotic figures, or moderate-to-high nuclear grade, and $\geq 5$ mitotic figures/50 HPF (18).

In conclusion, we reported a rare case of a glomus tumor arising in the duodenum. The characteristic strong and persistent enhancement on CT may be useful in differentiating glomus tumors from other subepithelial lesions. 


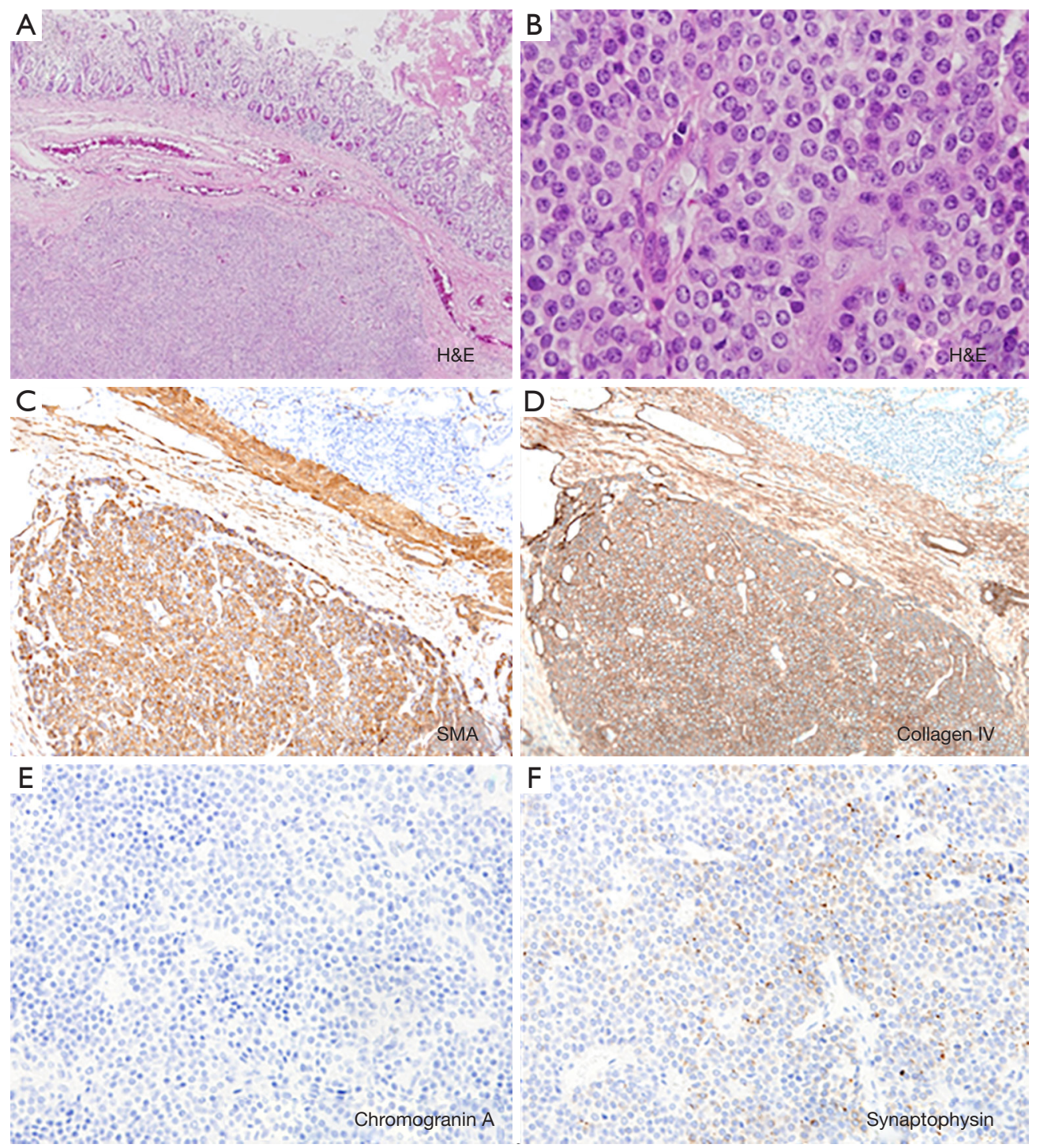

Figure 3 Histopathology of the duodenal glomus tumor. (A) The tumor involved the submucosa and muscularis propria ( $\times 40)$; (B) hematoxylin and eosin (H\&E) staining showed uniform small round cells with central nuclei and pale cytoplasm, no nuclear atypia, and no mitotic figures $(\times 400)$; (C,D) immunohistochemical staining showed positive expression for smooth muscle actin and collagen IV $(\times 40)$; (E,F) immunohistochemical staining showed negative expression of chromogranin A but focal positive expression of synaptophysin $(\times 40)$.

\section{Acknowledgments}

Funding: None.

\section{Footnote}

Conflicts of Interest: All authors have completed the ICMJE uniform disclosure form (available at http://dx.doi. org/10.21037/qims.2020.03.22). The authors have no conflicts of interest to declare.
Open Access Statement: This is an Open Access article distributed in accordance with the Creative Commons Attribution-NonCommercial-NoDerivs 4.0 International License (CC BY-NC-ND 4.0), which permits the noncommercial replication and distribution of the article with the strict proviso that no changes or edits are made and the original work is properly cited (including links to both the formal publication through the relevant DOI and the license). See: https://creativecommons.org/licenses/by-ncnd $/ 4.0 /$. 


\section{References}

1. WHO classification of tumours of the digestive system, 5th Editon. IARC Press, 2019.

2. Schiefer TK, Parker WL, Anakwenze OA, Amadio PC, Inwards CY, Spinner RJ. Extradigital glomus tumors: a 20-year experience. Elsevier. Proceedings of Mayo Clinic Proceedings, 2006.

3. Jundi M, Lack EE, Brun EA, Esquivel J, Kumar D. Glomus tumor of the duodenum: a case report. Int J Surg Pathol 2004;12:411-4.

4. Knackstedt C, Wasmuth H, Donner A, Trautwein C, Winograd R. Diagnosis of an unusual tumor in the duodenum. Endoscopy 2007;39:E94.

5. Hur BY, Kim SH, Choi JY, Rha SE, Lee MW, Kim SY, Han JK, Choi BI. Gastroduodenal glomus tumors: differentiation from other subepithelial lesions based on dynamic contrast-enhanced CT findings. AJR Am J Roentgenol 2011;197:1351-9.

6. Tarangelo NP, Ha K, Skole KS. Duodenal Glomus Tumor: A Rare Cause of Upper GI Bleeding. Clin Gastroenterol Hepatol 2016;14:e123-4.

7. Miettinen M, Paal E, Lasota J, Sobin LH. Gastrointestinal glomus tumors: a clinicopathologic, immunohistochemical, and molecular genetic study of 32 cases. Am J Surg Pathol 2002;26:301-11.

8. Lee HW, Lee JJ, Yang DH, Lee BH. A clinicopathologic study of glomus tumor of the stomach. J Clin Gastroenterol 2006;40:717-20.

9. Kim JK, Won JH, Cho YK, Kim MW, Joo HJ, Suh JH. Glomus tumor of the stomach: CT findings. Abdom Imaging 2001;26:303-5.

10. Dupuy DE, Raptopoulos V, Meyer D, Davidoff A. Sonographic findings in glomus tumor of the stomach. J
Clin Ultrasound 1989;17:219-21.

11. Imamura A, Tochihara M, Natsui K, Murashima $\mathrm{Y}$, Suga T, Yaosaka T, Fujinaga A, Koito K, Miyakawa H, Higashino K. Glomus tumor of the stomach: endoscopic ultrasonographic findings. Am J Gastroenterol 1994;89:271-2.

12. Kang G, Park HJ, Kim JY, Choi D, Min BH, Lee JH, Kim JJ, Kim KM, Park CK, Sohn TS, Kim S. Glomus tumor of the stomach: a clinicopathologic analysis of 10 cases and review of the literature. Gut Liver 2012;6:52-7.

13. Yoshida H, Asada M, Marusawa H. Gastrointestinal: Glomus tumor: A rare submucosal tumor of the stomach. J Gastroenterol Hepatol 2019;34:815.

14. Cha SH, Cho SB, Kim YW, Park CM. Helical CT appearance of glomus tumor of the stomach. Eur Radiol 2000;10:671-3.

15. Hu XY, Hu CH, Fang XM, Zhang TH. Glomus tumor of the gastric body: helical CT findings. Chin Med J (Engl) 2007;120:1289-91.

16. Patel TH, Horton KM, Hruban RH, Fishman EK. Glomus Tumor of the Stomach: Depiction by Multidetector CT and Three-Dimensional Volume Rendering Imaging. Case Rep Med 2010;2010:126095.

17. Lee H, Choi YS, Oh SC, Park JJ, Kim CW, Kim HK, Kim I. Malignant glomus tumors of the stomach-a report of 2 cases with multiple metastases. Korean J Pathol 2009; 43:358-63.

18. Folpe AL, Fanburg-Smith JC, Miettinen M, Weiss SW. Atypical and malignant glomus tumors: analysis of 52 cases, with a proposal for the reclassification of glomus tumors. Am J Surg Pathol 2001;25:1-12.

19. Song SE, Lee CH, Kim KA, Lee HJ, Park CM. Malignant glomus tumor of the stomach with multiorgan metastases: report of a case. Surg Today 2010;40:662-7.

Cite this article as: Yoon J, Kim K, Lee S. Imaging findings of glomus tumor at duodenum: a case description. Quant Imaging Med Surg 2020;10(5):1133-1137. doi: 10.21037/qims.2020.03.22 